\title{
Hemorrhagic Stroke Probably Caused by Exercise Combined With a Sports Supplement Containing B- Methylphenyl-ethylamine (BMPEA): A Case Report
}

\section{Citation}

Cohen, Pieter, Zeijlon, Rickard, Nardin, Rachel, Keizers, Peter H.J., Venhuis, Bastiaan. 2015.

Hemorrhagic Stroke Probably Caused by Exercise Combined With a Sports Supplement

Containing B-Methylphenyl-ethylamine (BMPEA): A Case Report. Annals of Internal Medicine 162 (12): 879-80.

\section{Permanent link}

http://nrs.harvard.edu/urn-3:HUL.InstRepos:40997747

\section{Terms of Use}

This article was downloaded from Harvard University's DASH repository, and is made available under the terms and conditions applicable to Open Access Policy Articles, as set forth at http:// nrs.harvard.edu/urn-3:HUL.InstRepos:dash.current.terms-of-use\#OAP

\section{Share Your Story}

The Harvard community has made this article openly available.

Please share how this access benefits you. Submit a story.

\section{Accessibility}




\section{Observations}

\section{Hemorrhagic Stroke Probably Caused by Exercise Combined With a Sports Supplement Containing $\beta$ - Methylphenylethylamine (BMPEA): A Case Report}

$\beta$-Methylphenylethylamine (BMPEA) is a chemical similar to amphetamine that has been

found in dietary supplements marketed to promote weight loss and improve exercise workouts. The U.S. Food and Drug Administration recently warned manufacturers to stop distributing these products because this chemical is a synthetic compound not found in the

plants listed on product labels. To our knowledge, this is the first identified case of a hemorrhagic stroke likely caused by BMPEA and exercise.

This article was published online first at www.annals.org on 12 May 2015.

Background: The U.S. Food and Drug Administration has warned consumers that an isomer of amphetamine, $\beta$-methylphenylethylamine (BMPEA), is found in many sports supplements (1). The health effects of this chemical in humans are unknown $(2,3)$.

Objective: To report a case of hemorrhagic stroke probably caused by exercise combined with BMPEA.

Case Report: A 53-year-old woman presented with 1 day of numbness and clumsiness in her left hand. She reported the sudden onset of symptoms 45 minutes after beginning a vigorous exercise routine that she had repeated several times weekly for a few years.

On examination, she was afebrile, blood pressure was $163 / 58 \mathrm{~mm} \mathrm{Hg}$, and heart rate was regular at 90 beats/min. She was alert with normal mental status. She had a subtle left pronator drift, but no definite weakness or dyscoordination in the limbs. She had 
hypesthesia involving the left upper arm, forearm, and hand. Reflexes were normal without a Babinski sign; gait was normal.

The patient had no important medical history and did not receive any medications. However, she reported having consumed the recommended dose $(13 \mathrm{~g})$ of a sports supplement (Jacked Power, MM Sports) 30 minutes before beginning exercise. She had not consumed this or any similar sports supplement previously. She was physically active and had always been of normal weight with low blood pressure. She quit smoking 22 years ago, drank alcohol occasionally, and did not use illicit drugs. She had no family history of stroke or coagulation disorders.

Laboratory results included levels of total cholesterol of $4.6 \mathrm{mmol} / \mathrm{L}(180 \mathrm{mg} / \mathrm{dL})$, triglycerides of $1.0 \mathrm{mmol} / \mathrm{L}(89 \mathrm{mg} / \mathrm{dL}$ ), high-density lipoprotein cholesterol of $2.1 \mathrm{mmol} / \mathrm{L}$ (81 mg/dL), low-density lipoprotein cholesterol of $2.3 \mathrm{mmol} / \mathrm{L}(90 \mathrm{mg} / \mathrm{dL})$, glucose of 5.3 $\mathrm{mmol} / \mathrm{L}(95 \mathrm{mg} / \mathrm{dL})$, and hemoglobin of $137 \mathrm{~g} / \mathrm{L}$; leukocyte count of $5.3 \# \times \# 10^{9} \mathrm{cells} / \mathrm{L}$; platelet count of $250 \# \times \# 10^{9}$ cells/L; international normalized ratio of 1.2 ; and partial thromboplastin time of $31 \mathrm{~s}$. An electrocardiogram was normal. Computed tomography of the head showed a $2-\mathrm{cm}$ hemorrhage in the right parietal lobe (Figure). Magnetic resonance imaging of the brain revealed the hemorrhage with no underlying abnormalities. Cerebral angiography showed no evidence of vasculitis, aneurysm, or other vascular malformation. Blood pressure normalized after admission and remained normal. She was discharged after 5 days with minor residual sensory symptoms.

Neither BMPEA nor Acacia rigidula was listed on the supplement label. After the initial report was published in Swedish (4), we analyzed the patient's Jacked Power supplement at the Netherlands' National Institute for Public Health and the Environment (RIVM) using ultraperformance liquid chromatography-quadrupole/time-of-flight mass spectrometry (Acquity UltraPerformance LC SYNAPT G2 QTOF, Waters). We performed a general screening for pharmaceuticals and drugs. $\beta$-Methylphenylethylamine was the only unlabeled pharmaceutical or drug found and was confirmed at $290 \mathrm{mg}$ per dose using standard addition experiments with BMPEA (Sigma-Aldrich) and amphetamine (Merck) as reference standards.

Discussion: Exercise combined with BMPEA, an isomer of amphetamine, probably caused this patient's stroke. Case reports are available of exercise-induced hemorrhagic stroke in otherwise healthy patients, and amphetamine has also been identified as a cause of hemorrhagic strokes in many case reports. However, the health effects of amphetamine's $\beta$ isomer, BMPEA, are unknown. This isomer was first synthesized in the 1930s as a potential replacement for amphetamine (a-methylphenethylamine) (3). In the 1930s and 1940s, researchers found that BMPEA increased blood pressure and heart rate in cats and dogs (3). However, to our knowledge, BMPEA's physiologic effects in humans have not been studied $(2,3)$. We categorize causality as "probable/likely," which the World Health Organization's Adverse Reaction Terminology defines as "A clinical event ... with a reasonable time relation 
to administration of the drug, unlikely to be attributed to concurrent disease or other drugs or chemicals and which follows a clinically reasonable response on withdrawal" (5).

$\beta$-Methylphenylethylamine is available in more than a dozen brands of supplements marketed to improve athletic performance and weight loss $(1,2,3)$. To our knowledge, this is the first identified case of a hemorrhagic stroke probably caused by exercise combined with BMPEA. It was reported to the appropriate European authorities and on 4 April 2015 to the U.S. Food and Drug Administration.

Physicians in the United States should report all suspected serious adverse events from dietary supplements to the U.S. Food and Drug Administration at www.safetyreporting.hhs.gov. In Europe, physicians should report these events to the appropriate national authority.

Pieter A. Cohen, MD

Harvard Medical School; Boston, Massachusetts

Rickard Zeijlon, MD

Sahlgrenska University Hospital; Gothenburg, Sweden

Rachel Nardin, MD

Harvard Medical School; Boston, Massachusetts

Peter H.J. Keizers, PhD

Bastiaan Venhuis, PhD

National Institute for Public Health and the Environment (RIVM); Bilthoven, the Netherlands

Disclosures: Authors have disclosed no conflicts of interest. Forms can be viewed at www.acponline.org/authors/icmje/ConflictOfInterestForms. do?msNum=L15-0106.

\section{References}

1. U.S. Food and Drug Administration. BMPEA in dietary supplements. 24 April 2015. Accessed at www.fda.gov/food/dietarysupplements/qadietarysupplements/ucm443790.htm on 28 April 2015.

2. Pawar RS, Grundel E, Fardin-Kia AR, Rader JI. Determination of selected biogenic amines in Acacia rigidula plant materials and dietary supplements using LC-MS/MS methods. J Pharm Biomed Anal. 2014;88:457-66. [PMID: 24176750] doi: $10.1016 / j . j p b a .2013 .09 .012$

3. Cohen PA, Bloszies C, Yee C, Gerona R. An amphetamine isomer whose efficacy and safety in humans has never been studied, $\beta$-methylphenylethylamine (BMPEA), is found in multiple dietary supplements. Drug Test Anal. 2015. [PMID: 25847603]

doi: $10.1002 /$ dta. 1793 
4. Zeijlon R, Andersson B. Hjärnblödning efter intag av prestationshöjaren "Jacked Power." Frisk kvinna insjuknade under träning efter en enda dos. Läkartidningen. 2014;111:1782-4. [PMID: 25699325]

5. Edwards IR, Aronson JK. Adverse drug reactions: definitions, diagnosis, and management. Lancet. 2000;356:1255-9. [PMID: 11072960]

Figure. Computed tomography scan of the head. Scan was obtained the day after onset of left arm numbness and clumsiness and shows a right parietal intracerebral hemorrhage. 